\title{
Two new species of Curcuma L. (Zingiberaceae) from Thailand
}

\author{
CHARUN MAKNOI ${ }^{1}$, SURAPON SAENSOUK ${ }^{2}$, PIYAPORN SAENSOUK ${ }^{3, \bullet}$, SARAYUT RAKARCHA ${ }^{4}$, \\ WORANART THAMMARONG ${ }^{4}$ \\ ${ }^{1}$ Romklao Botanic Gardens, The Botanical Garden Organization. Phitsanulok 65170, Thailand \\ ${ }^{2}$ Plant and Invertebrate Taxonomy and Its Applications Unit Group, Walai Rukhavej Botanical Research Institute, Mahasarakham University. Maha \\ Sarakham 44150, Thailand \\ ${ }^{3}$ Plant and Invertebrate Taxonomy and Its Applications Unit Group, Department of Biology, Faculty of Science, Mahasarakham University. Maha \\ Sarakham 44150, Thailand. `email: pcornukaempferia@yahoo.com \\ ${ }^{4}$ Queen Sirikit Botanic Gardens, The Botanical Garden Organization. Chiang Mai 50180, Thailand
}

Manuscript received: 7 August 2021. Revision accepted: 25 August 2021

\begin{abstract}
Maknoi C, Saensouk S, Saensouk P, Rakarcha S, Thammarong W. 2021. Two new species of Curcuma L. (Zingiberaceae) from Thailand. Biodiversitas 22: 3910-3921. Curcuma aruna and C. pitukii, two new species from northern Thailand, are described, illustrated, and photographed. They are endemic to Sukhothai and Lampang Provinces, northern Thailand, and the morphological characteristics of two new species are compared with their closest species, C. flaviflora, C. eburnea, and C. pierreana. Two new species, C. aruna and $C$. pitukii are assignable to Curcuma subgenus Ecomata. C. aruna is recognized by leaves ovate with thin chartaceous, fertile bracts 6-12, it's glabrous on nearly all parts of the plant, flowers yellow and labellum yellow with 2 darker yellow bands in the center. C. pitukii is recognized by bracts $20-40$ with purplish white to purple, corolla lobes purplish white to pale purple, staminodes white, and labellum white with an embossed yellow path along the midrib from base to apex. A detailed description, distribution, ecology, etymology, preliminary conservation status, and photographs of two new species are provided. A key to 20 species of Curcuma subgenus Ecomata in Thailand is presented.
\end{abstract}

Keywords: Curcuma flaviflora, C. eburnea, C. pierreana, Lampang, subgenus Ecomata, Sukhothai, taxonomy, Zingiberales

\section{INTRODUCTION}

Zingiberaceae (Zingiberales), or Ginger family, is one of the largest flowering families in monocotyledons, aromatic herbs, creeping horizontal or tuberous rhizomes with about 57 genera of about 1,600 species worldwide (KewScience 2021). It is widely distributed in the tropical zone throughout tropical Africa, Asia, and the Americas. Southeast Asia is located at the center of the diversity of the family Zingiberaceae (Saensouk and Saensouk 2021; Saensouk et al. 2021a, b). Zingiberaceae in Thailand is represented by more than 26 genera and over 300 species, and the numbers will most certainly rise (Larsen and Larsen 2006). It is important used for food, spices, medicine, dyes, cosmetics, perfume, and ornamental plants such as Alpinia mutica, Boesenbergia rotunda, Curcuma longa, $C$. parviflora, $C$. singularis, $C$. alismatifolia, $C$. thorelii, Kaempferia galanga, K. parviflora, K. rotunda, Zingiber officinale, Z. isanensis, etc. (Saensouk and Saensouk 2021). The genus Curcuma L. is one of the largest genera in the family Zingiberaceae with approximately 120 species (Leong-Škorničková et al 2020). This genus is mainly distributed from India to south China, Southeast Asia, Papua New Guinea, and northern Australia (Sirirugsa et al. 2007; Saensouk and Saensouk 2021; Saensouk et al. 2021a, b). This genus is also importantly used for food, spices, medicine, dyes, cosmetics, and ornamental plants such as Curcuma aeruginosa, C. longa (popular one for food and medicinal plant), C. alismatifolia (or Siam tulip, the popular one for ornamental plant) (Saensouk et al. 2016; Saensouk and Saensouk 2021).

The genus is most diverse in Thailand, where more than 50 species of three subgenera (Ecomata Škorničk. \& Šída f., Curcuma L. and Hitcheniopsis (Baker) K.Schum.) are reported. Recently, many new species of Curcuma were described from Thailand (e.g. Boonma and Saensouk 2019; Maknoiet al. 2019; Leong-Škorničková et al. 2020, 2021; Soonthornkalump et al. 2020, 2021; Saensouk et al. 2021a, b, c).

During the author's study of plant diversity in northern Thailand, two unknown species of Curcuma were collected and photographed. Later, the authors rechecked the unidentified specimen of Curcuma and after carefully consulting the relevant literature comparison of its morphological characters with the protologues and type material, we found that it clearly represents an undescribed species which we describe and illustrate below as Curcuma aruna and $C$. pitukii. Therefore, this study aimed to describe and illustrate below, Curcuma aruna and $C$. pitukii from the northern part of Thailand.

\section{MATERIALS AND METHODS}

Plant materials and photographs of Curcuma aruna Maknoi \& Saensouk were collected from 2020 to 2021 in Sukhothai Province, northern Thailand and additional 
second new species, Curcuma pitukii Maknoi, Saensouk, Rakarcha \& Thammar., was collected from Lampang Province, northern Thailand. The morphology is described under a stereomicroscope. Measurements were recorded from living, dry specimens and spirit specimens. Type specimens from both new species of morphologically similar species were compared, and verified, including using digital images available online, and all the published literature of Curcuma especially in subgenus Ecomata (Maknoi 2006; Maknoi et al. 2006; Sirirugsaet al. 2007; Chen et al. 2015; Maknoi et al. 2019; Leong-Škorničková et al. 2020; Saensouk et al. 2021a)with the living dry specimens and spirit specimens under a stereoscopic microscope. A preliminary conservation assessment was prepared based on the IUCN Red List categories. Photographs were taken from living specimens in the field.

\section{RESULTS AND DISCUSSION}

During the fieldwork aimed to study the species diversity of the plants in the northern part of Thailand, we found two species undescribed science in the genus Curcuma, the family Zingiberaceae. They have been collected from Sukhothai and Lampang Provinces. The taxonomic treatment, description, flowering period, etymology, distribution, preliminary conservation status, ecology, vernacular names, uses, notes, illustrations, and photographs of Curcuma aruna and C. pitukii (Figures 1-6 and Tables 1-2) were observed. Both species belong to subgenus Ecomata and an identification key for 20 species of subgenus Ecomata in Thailand is provided.

\section{Taxonomic treatment}

Curcuma aruna Maknoi \& Saensouk, sp. nov. Figures 1-3, Table 1-subgenus Ecomata

This species is similar to $C$. flaviflora in early flowering habits, short peduncle, no coma and yellow flowers. The leaves of $C$. aruna are ovate and glabrous on both surfaces, instead of leaves elliptic to oblanceolate and pubescent on both surfaces in C. flaviflora. The length of the corolla tube of $C$. aruna is shorter than in C. flaviflora (2.3-2.8 cm long in C. aruna vs $3.8-4.2 \mathrm{~cm}$ in C. flaviflora). The staminodes of $C$. aruna are obovate, whilst those of $C$. flaviflora are ovate to elliptic. The staminodes of $C$. aruna are larger than those of $C$. flaviflora $(2.2-2.6 \times 1.4-1.6 \mathrm{~cm}$ in $C$. aruna vs $2.0 \times 1.2 \mathrm{~cm}$ in C. flaviflora).

Type: THAILAND, Sukhothai Province, Thung Saliam District, 13 May 2020, Maknoi \& Intamma 1936(holotype QBG!; isotypes BKF!, KKU!).

Rhizomatous herb. Leafy shoots $25-50 \mathrm{~cm}$ tall. Bladeless sheath 3-4, 5-18 cm long, green, glabrous. Leaf-sheaths green, 10-20 cm long, glabrous; ligule shallowly bilobed, 2-4 mm long, lobes apices rounded, margin finely eroded, glabrous; petiole distinct, $2-3 \mathrm{~cm}$ long, glabrous; lamina ovate, 20-35 × 9-12 cm, apex acute, base rounded, glabrous on both surfaces, thin chartaceous. Inflorescence from rhizome before the leafy shoot; peduncle 5-8 cm long, greenish-white, glabrous, with 3-4 sheathing bracts, 3-6 cm long, glabrous; spike 5$8 \mathrm{~cm}$ long, 1.5-3 cm diam.; cincinus 1-3 flowers. Comma bract absent. Fertile bracts 6-12, narrowly ovate to elliptic, $2.5-4.5 \times 1.2-2.5 \mathrm{~cm}$, apex acuminate, green, glabrous. Bracteoles triangular, ca $2 \mathrm{~mm}$ long, glabrous. Flowers ca $5.8 \mathrm{~cm}$ long, exerted from bracts. Calyx tubular, $1.3-1.6 \mathrm{~cm}$ long, apex 3-lobed with a unilateral incision 4$7 \mathrm{~mm}$ long from the apex, translucent white, glabrous. Corolla tube slender, $2.3-2.8 \mathrm{~cm}$ long, outside white and glabrous at the basal part, yellowish and puberulent at the apical part, inside puberulent at the apical part; dorsal corolla lobe lanceolate, 18-20 × 6-8 mm, apex acutemucronate, mucro ca $1 \mathrm{~mm}$ long, yellow, glabrous; lateral corolla lobes lanceolate, 16-19 × 5-7 mm, apex acute, yellow, glabrous. Lateral staminodes obovate, 2.2-2.6 $\times$ 1.4-1.6 cm, apex rounded, yellow. Labellum obovate, 2.4$2.8 \times 1.5-1.7 \mathrm{~cm}$, sinus $0.5-0.7 \mathrm{~cm}$ depth, yellow with 2 darker yellow bands in the center. Stamen ca $1.4 \mathrm{~cm}$ long, yellow; filament flat, 4-5 × 2-3 mm, puberulent; anther 8 $9 \times 1.5 \mathrm{~mm}$; anther spurs 3-4 mm long, point forwards, apex slightly curved outwards; anther crest not obvious; anther thecae 6-7 mm long. Ovary subspherical, ca $2 \times 2$ $\mathrm{mm}$, glabrous; epigynous gland 2, cylindrical, ca $5 \mathrm{~mm}$ long; style slender, white, glabrous; stigma yellow, ca 1 $\mathrm{mm}$ long. Fruit and Seed not seen.

Distribution: Endemic to Thailand, currently found only in the type locality.

Ecology: Scrub forest foothill of limestone, 100-150 m a.s.l.

Phenology: Flowering in May, early rainy season.

Vernacular name: Krachiao Arun (Krachiao in Thai means Curcuma and arun means dawn in Thai).

Etymology: The specific epithet of the new species is "aruna", which means "dawn" in Thai, refer to flower color resemble the color of the dawn and name of God of the Dawn in Thai mythology. The name of the type locality province "Sukhothai" means the dawn of happiness also.

Preliminary conservation status: Curcuma aruna is endemic to Thailand and currently known only from the type location. Based on the known information, we propose to preliminary treat this plant as Endangered species [EN: $B 2 a b(i i), C 2 a(i)]$, according to IUCN Standards and Petitions Committee (2019). Further fieldwork is needed as suitable habitats still seem to exist, to assess changes in population, distribution, and abundance in the future.

Uses: Auspicious ornamental plant.

Note: This species belongs to the subgenus Ecomata Škorničk. \& Šída f. (Záveská et al. 2012) because of lacking coma bracts, presence of epigynous gland and anther spurs, and fertile bracts connate only at the base. $C$. aruna is recognized by lamina ovate with thin chartaceous, fertile bracts 6-12, it's glabrous on nearly all parts of the plant, flowers yellow and labellum yellow with 2 darker yellow bands in the center. Curcuma aruna is the most similar to $C$. flaviflora having a similar color of the flower and numbers of bracts but $C$. aruna was found in scrub forest foothill of limestone, alt. 100-150 m (vs C. flaviflora was found in the pine forest, alt. 1,200 $\mathrm{m}$ or higher). In 
addition, $C$. aruna can be clearly distinguished from $C$. flaviflora in the diagnosis and a comparison showing in Table 1 and Fig. 3.

Curcuma pitukii Maknoi, Saensouk, Rakarcha \& Thammar., sp. nov. -Figures 4-6, Table 2-subgenus Ecomata

Curcuma pitukii is most similar to Curcuma eburnea Škorničk., Suksathan \& Soonthornk. by its terminal inflorescence, the number of bracts, without coma bracts, and small filiform anther spurs. The leaves of $C$. pitukii are densely puberulent on the adaxial surface, but the leaves of C. eburnea are glabrous on the adaxial surface. C. pitukii has purplish white to purple bracts, whilst $C$. eburnea has cream-white or pale greenish bracts. The length of the calyx of $C$. pitukii is longer than in C. eburnea $(14-18 \mathrm{~mm}$ long in $C$. pitukii vs $8-10 \mathrm{~mm}$ long in $C$. eburnea). The length of the corolla tube of $C$. pitukii is shorter than in $C$. eburnea (2.2-3 cm long in $C$. pitukii vs $3.5 \mathrm{~cm}$ long in $C$. eburnea). The corolla lobes of $C$. pitukii are purplish white to pale purple and sparsely puberulent at the apex, but in $C$. eburnea they are pure white and glabrous. The length of the filament of $C$. pitukii is longer than in C. eburnea (5-8 $\mathrm{mm}$ long in $C$. pitukii vs $2 \mathrm{~mm}$ long in $C$. eburnea). The length of the anther of $C$. pitukii is shorter than in $C$. eburnea (2.5-4 $\mathrm{mm}$ long in $C$. pitukii vs $8-9 \mathrm{~mm}$ long in $C$. eburnea).

Type: THAILAND, Lampang Province, Sop Prap District, 20 August 2020, S. Rakarcha, W. Thammarong, S. Wongwan \& M. Tabut 940 (holotype QBG!; isotypes BKF!, KKU!).

Perennial herb. Rhizome ovoid to elliptic, $2.2-4 \times 1.8-2$ $\mathrm{cm}$, outside light brown, inside pale yellow. Root fibrous and bearing ovate to elliptic tubers, $2.5-4.5 \times 1.3-2 \mathrm{~cm}$, inside translucent white. Leafy shoots $35-50 \mathrm{~cm}$ tall. Bladeless sheaths 2-3, 5-18 cm long, margin ciliate, reddish, adaxially glabrescent, abaxially puberulent. Leaves 2-5; leaf sheaths 12-20 cm long, margin ciliate, reddish, adaxially glabrescent, abaxially puberulent; ligule bilobed, ca $2 \mathrm{~mm}$ long, densely puberulent; petiole canaliculate, 9$15 \mathrm{~cm}$ long, green to reddish, puberulent; lamina elliptic, 22-32 × 9-12 cm, apex acute, base cuneate to rounded, adaxially green, densely puberulent, abaxially pale green, glabrescent with sometimes densely puberulent running near margin, ca $0.5 \mathrm{~mm}$ wide. Inflorescence terminal; peduncle 3-7 cm long, greenish-white, puberulent; spike 6$9 \mathrm{~cm}$ long, 4-5 cm diam.; cincinnus 2-4 flowers. Comma bract absent. Fertile bracts $20-40$, broadly ovate, 1.8-3.5 $\times$ $2.5-4.5 \mathrm{~cm}$, connate $4-5 \mathrm{~mm}$ at the base, apex acute, margin entire, purplish-white to purple, adaxially glabrescent, abaxially puberulent at the base, sparsely puberulent towards apical part. Bracteoles small, narrowly triangular, ca $4 \times 2 \mathrm{~mm}$, sometimes fully reduced (absent). Flowers 4-5 cm long, exerted from bracts. Calyx tubular, 14-18 mm long, apex 3-lobed with a unilateral incision 3-6 $\mathrm{mm}$ long from apex, pale purple, puberulent, 2 lobes apices mucronate with sparsely puberulent. Corolla tube $2.2-3 \mathrm{~cm}$ long, narrowly cylindrical at the base, funnel-shaped at apex, outside purplish-white or pale purple, puberulent, inside white, glabrous at basal part, with a ring of densely hairs at ca $2 \mathrm{~cm}$ from the base, puberulent at funnel-shaped; dorsal corolla lobe triangular-lanceolate, 16-22 × 5-8 mm, apex mucronate, mucro ca $1 \mathrm{~mm}$, purplish-white to pale purple at basal part with increasing purple tinge towards the apical part, glabrous at basal part with sparsely puberulent at apex and mucro; lateral corolla lobe triangular-lanceolate, $12-19 \times 4-7 \mathrm{~mm}$, apex broadly acute, purplish-white to pale purple at basal part with increasing purple tinge towards the apical part, glabrous at basal part with sparsely puberulent at the apex. Lateral staminodes irregularly elliptic, $12-17 \times 7-12 \mathrm{~mm}$, white, adaxially puberulent, abaxially sparsely puberulent to glabrous. Labellum irregularly obovate-rhomboid, 14-20 × 8-14 $\mathrm{mm}$, sinus 2-3 mm depth, white with an embossed yellow path along the center from base to apex (divided into two patches at the base like a Y-shape), minutely puberulent on either side of mid-band. Stamen 8-11 mm long, white; filament flat, 5-8 × 2-3 mm, puberulent; anther 2.5-4 mm long, white, connective tissue puberulent; anther spurs small, ca $0.8 \mathrm{~mm}$ long, filiform; anther crest $1-3 \mathrm{~mm}$ long, apex slightly emarginate. Ovary oblong, 3-6 × 1.5-2 mm, trilocular, white, densely puberulent or rarely sparsely puberulent; epigynous gland 2, cylindrical, 3-6 mm long, pale yellow; style white, glabrous; stigma capitate, 1-1.5 mm wide, ostiole ciliate, white. Fruit obovate, 8-12 × 6-8 $\mathrm{mm}$, pure white with red dots towards the apical part, glabrous; seed elliptic, 3-5 × 2-3 mm, light brown with white aril.

Distribution: Endemic to Thailand.

Ecology: It grows on clay loamy soil in the shade in deciduous forest, altitude $700 \mathrm{~m}$ a.s.1.

Phenology: Flowering and fruiting in August.

Vernacular: Cho MuangPituk(Cho in Thai name means inflorescence, Muang means purple, and Pituk is the first name of Mr.Pituk Punyajun).

Etymology: The specific epithet "pitukii" is named in honor of "Mr.Pituk Punyajun", a supporter and backup plant taxonomists in Thailand for over 25 years and who first found the plant.

Preliminary conservation status: Curcuma pitukii is endemic to Thailand and currently known only from the type location. The total number of individuals is less than 250 and the distribution area is less than $500 \mathrm{~km}^{2}$. Therefore, the conservation status is provisionally evaluated as Endangered [EN: B2ab(ii), C2a(i)], according to IUCN Standards and Petitions Committee (2019).

Uses: The mature rhizomes (fresh) of this plant by local villagers are used in Thai traditional medicine to treat gastritis and relieve flatulence. In addition, they ate young fresh rhizomes as vegetables

Note: The species belongs to subgenus Ecomata Škorničk. \& Šída f. (Záveská et al. 2012). Considering the two closest species namely Curcuma eburnea and $C$. pierreana have terminal inflorescence without comma bract, presence of epigynous gland, and small filiform anther spurs. These three species can be easily distinguished by the indumentum of leaves, number and color of bracts, the length and color of calyx, proportions, and color of various flower parts, and indumentum of flowers. Morphologically, C. pitukii is most similar to $C$. 
eburnea by the number of bracts, white staminodes, and white with a yellow medium band running through the center of the labellum, but sometimes the color of staminode of $C$. eburnea is white with a yellowish patch in the center and the apex. In addition, $C$. pitukii can be clearly distinguished from $C$. eburnea in the diagnosis and a comparison showing in Table 2 . It is also similar to $C$. pierreana by its small filiform anther spurs and ovary hairy but differs in 20-40 bracts (vs10-20 bracts in $C$. pierreana), purplish-white to purple bract (vs cream-white bracts in C. pierreana), and white staminode (vs white with dark purple tips of staminode in $C$. pierreana). The other morphological differences between $C$. pitukii and similar species are provided in Table 2.

\section{Key to 20 species of Curcuma subgenus Ecomata in Thailand}

1. Corolla tube longer than bracts, narrow; flowers yellow; petiole very distinct from leaf blade

1. Corolla tube short, wide, flowers of various colors, leaf-blade tapering into the petiole

2. Anther spurs filamentose, $0.5-2 \mathrm{~mm}$ long

3. Staminodes white with dark purple tips

C. supraneeana

3. Staminodes white or white with yellowish patch in center and apex

4. Fertile bracts less than 20

5. Leaves puberulous on both surfaces, staminodes white with a yellow patch in the center

5. Leaves upper surface glabrous; staminodes pure white

4. Fertile bract more than 20

6. Leaves glabrous on both surfaces, bracts cream-white or pale greenish

6. Leaves densely puberulent on the upper surface, bracts purplish white to purple

2. Anther spurs conical or cylindrical, forward-pointed, longer than $2 \mathrm{~mm}$ long

7. Inflorescence terminal

8. Leaves upper glabrous

9. Staminodes yellow or light orange; leaves lower glabrous

10. Labellum approx. reniform, oblique, yellow with inside half orange, apex acute turning outward; staminodes rhomboid, light orange with dotted dark red at base, apex rounded; leaves glabrous on both

C. pierreana

10. Labellum ovate, yellow with dark yellow band in the middle and light pale yellow at base, apex obtuse; staminodes asymmetrical trullate to ovate, yellow with pale yellow at base, apex obtuse; glabrous on both surfaces except a few shortly hairy at tip

9. Staminodes white; leaves lower pubescent

11. Labellum diamond-shaped, white with yellow patch in center and red spots at base; white with dark purple spots at base

11. Labellum suborbicular, white with two deep orange bands at the center with deep purple lines at the base

C. chantaranothaii

C. cochinchinensis

C. eburnea

C. pitukii

C. rhomba

C. rangsimae

C. peramoena

C. woodii

8. Leaves upper pubescent

12. Corolla lobes whitish-green to pale green; leaves base cuneate to attenuate

12. Corolla lobes pink, red or purple; leaves base oblique, rounded or cordate

13. Leaves lower glabrous; staminodes lanceolate, subacute, yellow

13. Leaves lower pubescent

14. Staminodes elliptic, lower half dark red, upper half orange-yellow, base with pyramidal lump, apex rounded, ventral side pilose, margins with globular dots

14. Staminodes oblique obovate, pale yellow, glabrous on both sides

C. bicolor

7. Inflorescence lateral

15. Staminodes purple

15. Staminodes white or yellow or white with yellow

16. Labellum yellow

17. Leaves elliptic to oblanceolate and pubescent on both surfaces, staminodes ovate to elliptic

17. Leaves ovate and glabrous on both surfaces, staminodes obovate

C. flaviflora

C. aruna

16. Labellum white with a yellow median band

18. Leaves upper green with red patch along the midrib

C. candida

18. Leaves upper green without red patch along the midrib

19. Staminodes lower half white, upper half golden yellow, central purple patch covered with dense

19. Staminodes white 
Table 1. Morphological comparison between Curcuma aruna and C. flaviflora

\begin{tabular}{|c|c|c|}
\hline Characters & C. aruna & C. flaviflora \\
\hline Leaf & ovate, $20-35 \times 9-12 \mathrm{~cm}$ & elliptic to oblanceolate, $18-30 \times 6-8.5$ \\
\hline Leaf indumentum & glabrous on both surfaces & pubescent on lower leaf surface \\
\hline Bract & $\begin{array}{l}\text { narrowly ovate to elliptic, } 2.5-4.5 \times 1.2-2.5 \mathrm{~cm} \text {, } \\
\text { green, glabrous }\end{array}$ & $\begin{array}{l}\text { ovate to lanceolate, } 3-4.5 \\
\times 1.3-2.6 \mathrm{~cm} \text {, pale purplish red, densely pubescent } \\
\text { on both surfaces }\end{array}$ \\
\hline Calyx & $1.3-1.6 \mathrm{~cm}$ long, glabrous & $21 \mathrm{~mm}$ long, hairy along ridges \\
\hline Corolla tube & $2.3-2.8 \mathrm{~cm}$ long, puberulent & $3.8-4.2 \mathrm{~cm}$ long, pubescent \\
\hline Staminodes & obovate, $2.2-2.6 \times 1.4-1.6 \mathrm{~cm}$ & ovate to elliptic, ca $2 \times 1.2 \mathrm{~cm}$ \\
\hline Labellum & obovate, $2.4-2.8 \times 1.5-1.7 \mathrm{~cm}$ & obovate, ca $2 \times 1.5 \mathrm{~cm}$ \\
\hline Ecology & $\begin{array}{l}\text { scrub forest foothill of limestone, } 100-150 \mathrm{~m} \\
\text { above sea level }\end{array}$ & $\begin{array}{l}\text { open areas in pine forests, } 1,200 \mathrm{~m} \text { above sea level } \\
\text { or higher }\end{array}$ \\
\hline
\end{tabular}

Table 2. Morphological comparison between Curcuma eburnea, C. pierreana, and C. pitukii

\begin{tabular}{|c|c|c|c|}
\hline Characters & C. eburnea & C. pierreana & C. pitukii \\
\hline Internally rhizome & light yellow & pale brown & pale yellow \\
\hline $\begin{array}{l}\text { Adaxial surface of } \\
\text { lamina }\end{array}$ & bright green, glabrous & $\begin{array}{l}\text { green with reddish-brown patch } \\
\text { along midrib, glabrous }\end{array}$ & green, densely puberulent \\
\hline $\begin{array}{l}\text { Abaxial surface of } \\
\text { lamina }\end{array}$ & $\begin{array}{l}\text { lighter green, puberulent, } \\
\text { midrib green, glabrous }\end{array}$ & green, densely short-hairy & $\begin{array}{l}\text { pale green, glabrescent with sometimes } \\
\text { densely puberulent running near margin, } \\
\text { ca } 0.5 \mathrm{~mm} \text { wide }\end{array}$ \\
\hline Leaf base & $\begin{array}{l}\text { oblique, rounded to } \\
\text { subcordate }\end{array}$ & cuneate to attenuate & cuneate to rounded \\
\hline $\begin{array}{l}\text { Number of fertile } \\
\text { bracts }\end{array}$ & $30-40$ & $10-20$ & $20-40$ \\
\hline Bract & $\begin{array}{l}\text { broadly ovate to trullate, } \\
\text { cream-white or pale greenish, } \\
\text { glabrous on both sides }\end{array}$ & $\begin{array}{l}\text { broadly ovate, whitish or } \\
\text { greenish, hairy }\end{array}$ & $\begin{array}{l}\text { broadly ovate, purplish-white to purple, } \\
\text { adaxially glabrescent, abaxially } \\
\text { puberulent at base, sparsely puberulent } \\
\text { towards apical part }\end{array}$ \\
\hline Calyx & $\begin{array}{l}8-10 \mathrm{~mm} \text { long, } \\
\text { semitranslucent white, } \\
\text { glabrous }\end{array}$ & $\begin{array}{l}\text { ca } 16 \mathrm{~mm} \text { long, scattered fine } \\
\text { hairy }\end{array}$ & $14-18 \mathrm{~mm}$ long, pale purple, puberulent \\
\hline Corolla tube & ca $3.5 \mathrm{~cm}$ long & ca $3.2 \mathrm{~cm}$ long & $2.2-3 \mathrm{~cm}$ long \\
\hline Corolla lobe & $\begin{array}{l}14-18 \times 10-12 \mathrm{~mm} \text {, } \\
\text { triangular-ovate or triangular } \\
\text { with rounded, pure white, } \\
\text { glabrous }\end{array}$ & $12 \times 7-9 \mathrm{~mm}$, white, glabrous & $\begin{array}{l}12-22 \times 4-8 \mathrm{~mm} \text {, triangular-lanceolate } \\
\text { purplish to pale purple at base with } \\
\text { increasing purple tinge towards the apical } \\
\text { part, glabrous at basal part with sparsely } \\
\text { puberulent at apex and mucronate }\end{array}$ \\
\hline Staminode & $\begin{array}{l}\text { ca } 15 \times 12 \mathrm{~mm} \text {, white or with } \\
\text { yellowish patch in the center } \\
\text { and the apex }\end{array}$ & $\begin{array}{l}\text { ca } 15 \times 12 \mathrm{~mm} \text {, white with } \\
\text { maroon tips }\end{array}$ & $12-17 \times 7-12 \mathrm{~mm}$, white \\
\hline Labellum & $\begin{array}{l}18-20 \times 17-18 \mathrm{~mm} \text {, obscurely } \\
\text { trilobed, white with a bright } \\
\text { yellow medium band running } \\
\text { through the center }\end{array}$ & $\begin{array}{l}\text { ca } 15 \times 12 \mathrm{~mm} \text {, broadly } \\
\text { obovate, white with yellow } \\
\text { band at the center with maroon } \\
\text { tips }\end{array}$ & $\begin{array}{l}14-20 \times 8-14 \mathrm{~mm} \text {, irregularly obovate- } \\
\text { rhomboid, white with embossed yellow } \\
\text { path along the midrib from base to apex }\end{array}$ \\
\hline Filament & $2 \mathrm{~mm}$ long & ca $2 \mathrm{~mm}$ long & 5-8 mm long \\
\hline Anther & $\begin{array}{l}8-9 \mathrm{~mm} \text { long; spurs } 1-1.5 \mathrm{~mm} \\
\text { long; crest } 1.5-2 \mathrm{~mm} \text { long, } \\
\text { apex rounded }\end{array}$ & $\begin{array}{l}\text { ca } 6 \mathrm{~mm} \text { long; spur ca } 1 \mathrm{~mm} \\
\text { long; crest quadrangular ca } 1 \\
\text { mm long, apex truncate }\end{array}$ & $\begin{array}{l}2.5-4 \mathrm{~mm} \text { long; spurs ca } 0.8 \mathrm{~mm} \text { long; } \\
\text { crest } 1-3 \mathrm{~mm} \text { long, apex slightly } \\
\text { emarginate }\end{array}$ \\
\hline
\end{tabular}



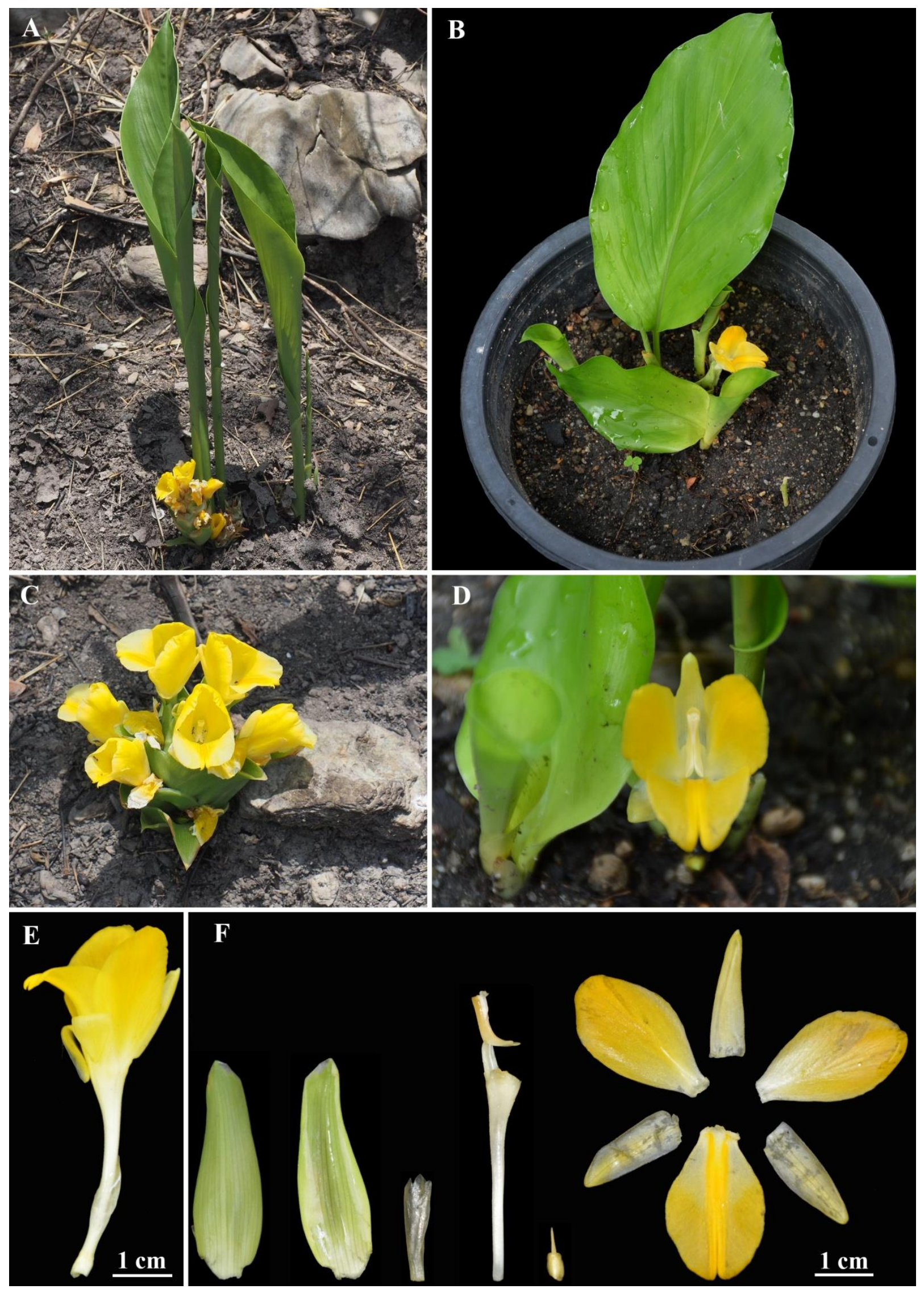

Figure 1. Curcuma aruna Maknoi \& Saensouk: A. and B. habit; C.inflorescence; D. flower in front view; E. flower in side view; F. flower dissection (from left: abaxial of bract, adaxial of bract, calyx, floral tube with stamen, ovary with epigynous gland, lateral staminode, labellum, dorsal and lateral corolla lobes). Photographed by C. Maknoi (A, C from type location); S. Rakarcha (B, D-F from cultivation) 

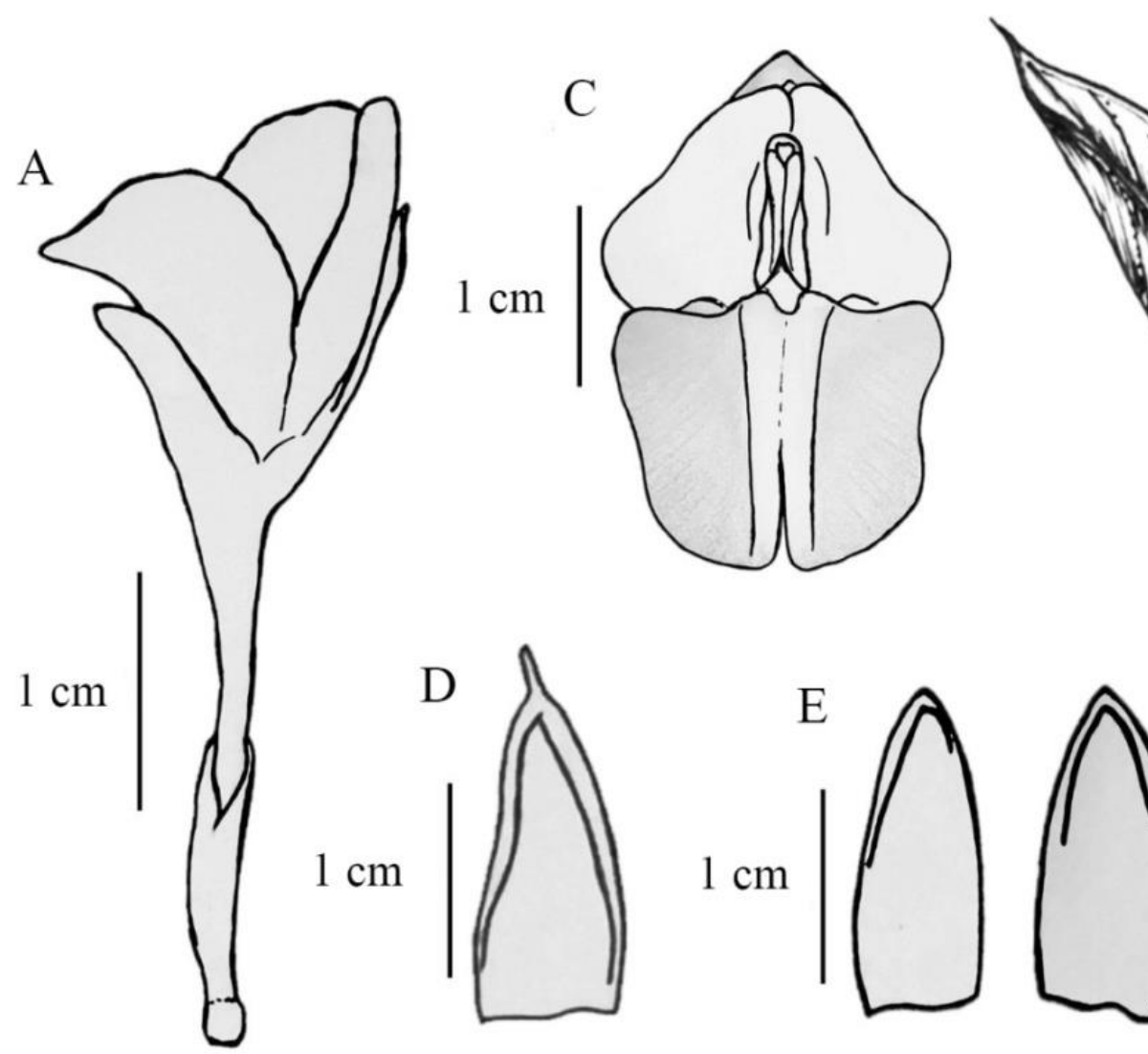

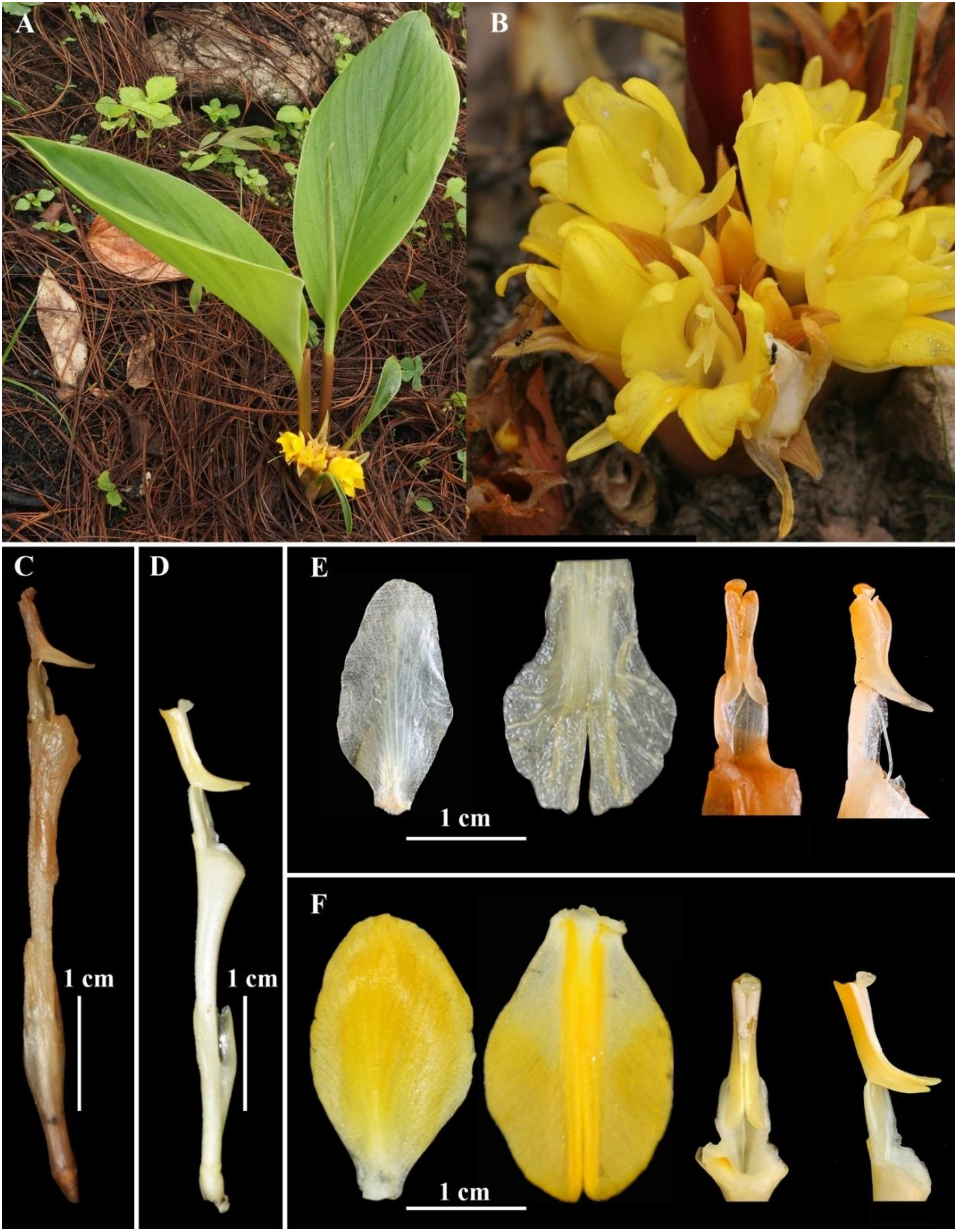

Figure 3. Comparison of Curcuma aruna and C. flaviflora. C. flaviflora: A. habit; B. inflorescence; C. corolla tube with ovary, calyx, and stamen; E. flower dissection (from left: lateral staminode, labellum, stamen in front view, and stamen in side view). C. aruna: D. corolla tube with ovary, calyx and stamen; F. flower dissection (from left: lateral staminode, labellum, stamen in front view and stamen in side view). Photographed by W. Pongamornkul (A, B from Doi Ang Khang, Chiang Mai, N. Thailand); S. Rakarcha (C, E from Maknoi 356 (QBG); D, F from cultivation) 

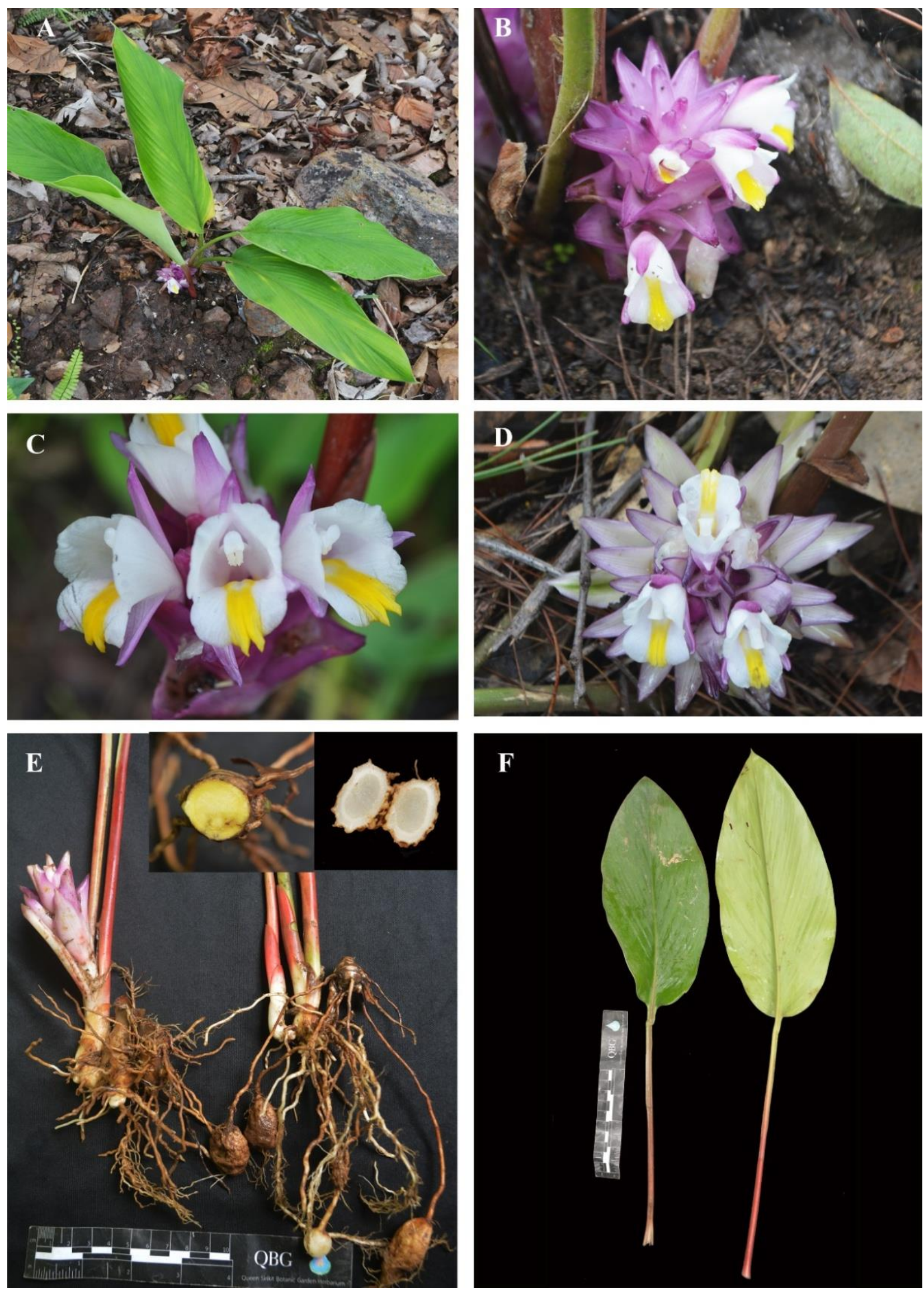

Figure 4. Curcuma pitukii Maknoi, Saensouk, Rakarcha \& Thammar.: A. habit; B. inflorescence; C. close up flowers; D. inflorescence (top view); E. rhizome and roots (inset: detail of rhizome and root tubers); F. leaf. Photographed by S. Rakarcha 

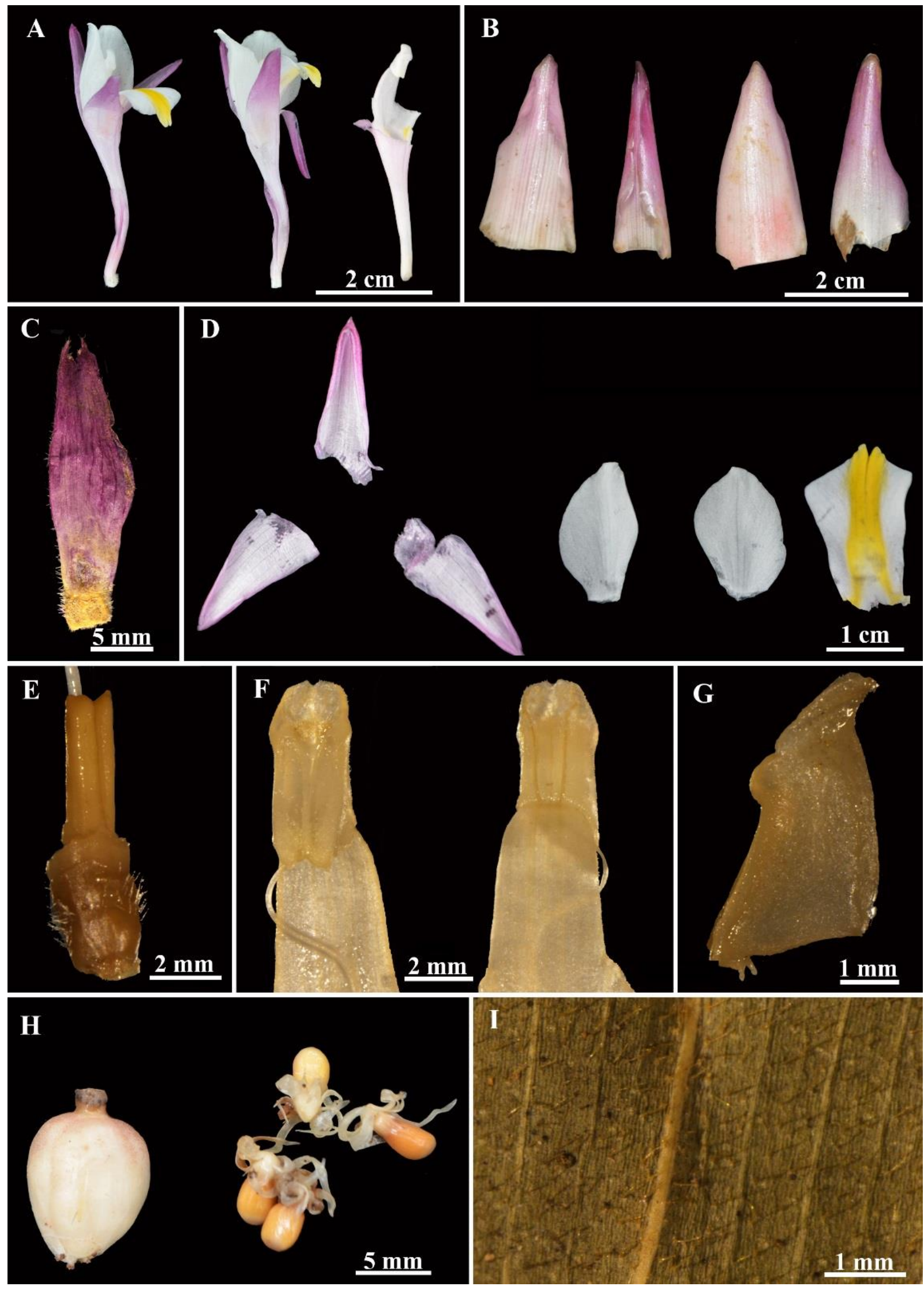

Figure 5. Curcuma pitukii Maknoi, Saensouk, Rakarcha \& Thammar.: A. flower in side view and corolla tube with stamen; B. bracts; C. ovary with calyx; D. corolla lobes, lateral staminode and labellum, from left to right; E. ovary with epigynous gland; F. front and back view of anther; G. side view of anther; H. fruit and seeds; I. adaxial surface of lamina. Figure $2 \mathrm{E}-\mathrm{G}$ photographed from a specimen preserved in alcohol, while figure 2C and 2I photographed from dry specimens. Photographed by S. Rakarcha. 

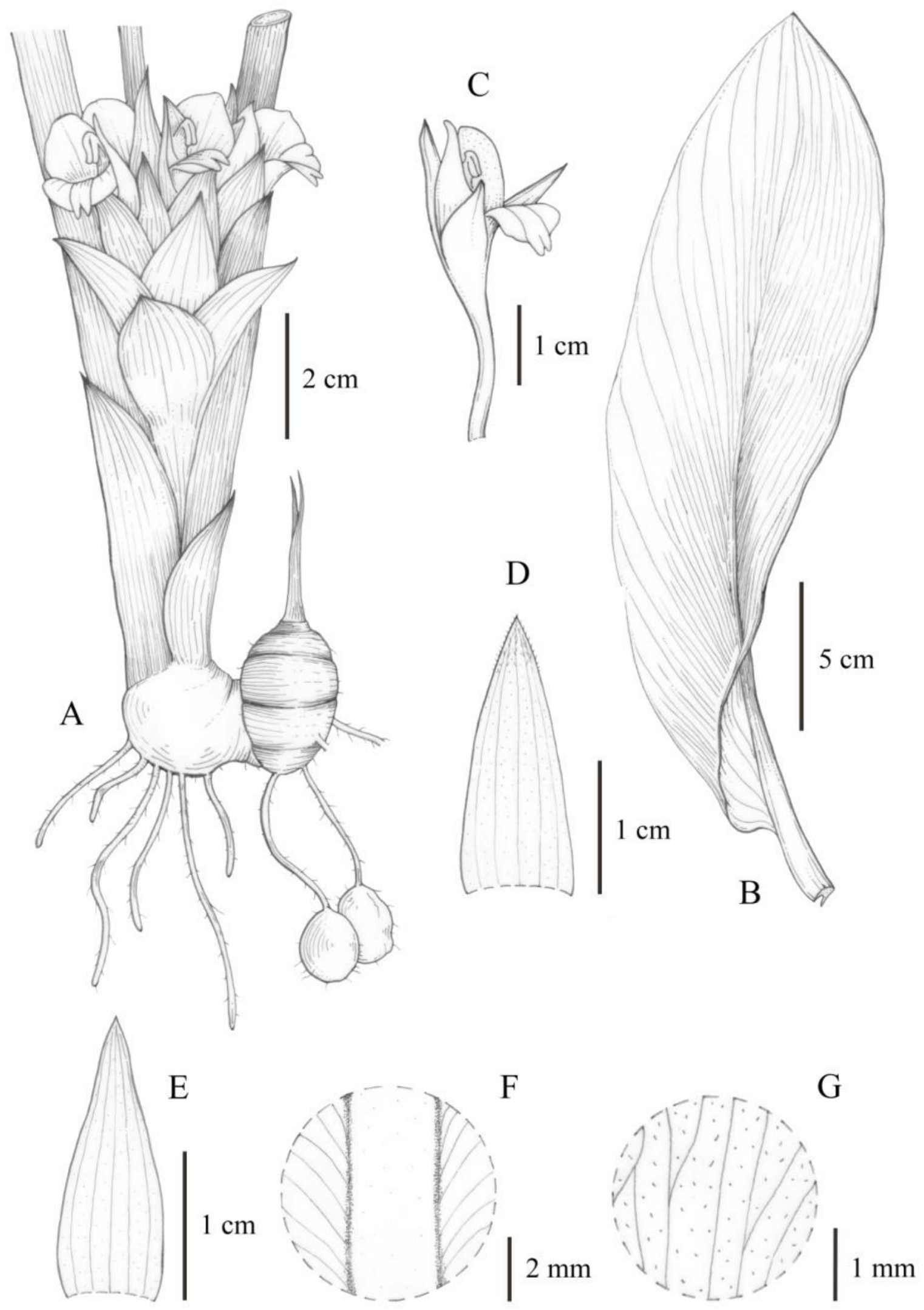

Figure 6. Curcuma pitukii Maknoi, Saensouk, Rakarcha \& Thammar.: A. habit; B. leaf.; C. flower without calyx and ovary; D. abaxial surface of dorsal corolla lobe; E. abaxial surface of lateral corolla lobe; F. adaxial surface of labellum; G. adaxial surface of lateral staminode. Drawn by W. Thammarong 


\section{ACKNOWLEDGEMENTS}

The authors wish to thank the staff of the Queen Sirikit Botanic Garden for assistance in the field. This work was supported by the Botanical Garden Organization, Thailand. The funding of the third and fourth authors provided by the research project of the assessment of threatened plants on limestone in Thailand. The research project of the second author is financially supported by the Biodiversity-Based Economy Development Office (Public Organization) or "BEDO". We are deeply indebted to Mahasarakham University, Walai Rukhavej Botanical Research Institute and the Botanical Garden Organization for their facilities support during this study. Many thanks to Mr.Thawatphong Boonma for the line drawing assistance of Curcuma aruna and Mr. WittayaPongamornkul for helping us and photograph C. flaviflora. Warm thanks also to the Curators and staff of the herbaria visited (KUN and QBG).

\section{REFERENCES}

Boonma T, Saensouk S. 2019. Curcuma saraburiensis (Zingiberaceae), a new species from Thailand. Taiwania 64(3): 245-248.

Chen J, Lindstron AJ, Xia HN. 2015. Curcuma woodii (Zingiberaceae), a new species from Thailand. Phytotaxa 227(1): 075-082.

IUCN Standards and Petitions Committee. 2019. Guidelines for Using the IUCN Red List Categories and Criteria. Version 14. Prepared by the Standards and Petitions Committee.

Kew Science 2021. World Checklist of selected plant families (WCSP). http://apps.kew.org/wcsp/

Larsen K, Larsen SS. 2006. Gingers of Thailand. Queen Sirikit Botanic Garden, The Botanical Garden Organization, Chiang Mai.

Leong-Škorničková J, Soonthornkalump S, Suksathan P. 2020. Curcuma cinnabarina and C. eburnea (Zingiberaceae: Zingiberoideae), two new species from Thailand. Edinburgh Journal of Botany 77(3): 391 402. DOI: $10.1017 /$ S0960428620000049

Leong-Škorničková J, Soonthornkalump S, Thongbai W. 2021. Four new Curcuma species (Zingiberaceae) from Thailand. Blumea 65(3): 244253.
Maknoi C. 2006. Taxonomy and phylogeny of the genus Curcuma L. (Zingiberaceae) with particular reference to its occurrence in Thailand. Dissertation, Prince of Songkla University, Songkhla, Thailand.

Maknoi C, Sirirugsa P, Larsen K. 2006. New records of Curcuma L. in Thailand. Thai Forest Bulletin (Botany) 33: 71-74

Maknoi C, Ruchisansakun S, Jenjittikul T. 2019. Curcuma putii (Zingiberaceae), a new species from Thailand. Annales Botanici Fennici 56(4-6): 351-353. DOI: 10.5735/085.056.0420

Saensouk S, Saensouk P, Pasorn P, Chantaranothai P. 2016. Diversity, traditional uses, and a new record of Zingiberaceae in Nam NaoNational Park, Petchabun Province, Thailand. Agriculture and Natural Resources 50:445-453. DOI: 10.1016/j.anres.2016.08.002

Saensouk P, Saensouk S. 2021. Diversity, traditional uses, and conservation status of Zingiberaceae in Udorn Thani province, Thailand. Biodiversitas 22(8): 3083-3097. DOI: 10.13057/biodiv/d220801

Saensouk S, Boonma T, Saensouk P. 2021a. Six new species and a new record of Curcuma L. (Zingiberaceae) from Thailand. Biodiversitas 22(4): 1658-1685. DOI: 10.13057/biodiv/d220410

Saensouk S, Boonma T, Thomudtha A, Thomudtha P, Saensouk P. 2021b. Curcuma wanenlueanga (Zingiberaceae), a new species of subgenus Curcuma from Thailand. Biodiversitas 22(7): 2988-2994. DOI: 10.13057/biodiv/d220752

Saensouk S, Boonma T, Saensouk P. 2021c. A new species and a new record of Curcuma subgen. Curcuma (Zingiberaceae) from Northern Thailand. Biodiversitas 22(9): 3617-3626.

Sirirugsa P, Larsen K, Maknoi C. 2007. The genus Curcuma L. (Zingiberaceae) distribution and classification with reference to species diversity in Thailand. Garden's Bulletin Singapore 59(1\&2): 203-220.

Soonthornkalump S, Ongsakul A, Dolaji A, Leong-Škorničková J. 2020. Curcuma papilionacea (Zingiberaceae), an unusual new species from southern Thailand. Phytotaxa 432(1): 11-16. DOI: 10.11646/phytotaxa.432.1.2

Soonthornkalump S, Puangpairote T, Niwesrat S, Leong-Škorničková J. 2021. Curcuma lithophila and C. rufostriata (Zingiberaceae), two new species from Thailand, and additional notes on $C$. papilionacea. Thai Forest Bulletin (Botany) 49(1): 32-43. DOI: 10.20531/tfb.2021.49.1.03

Záveská E, Fér T, Šída O, Krak K, Marhold K, Leong-Škorničková J. 2012. Phylogeny of Curcuma (Zingiberaceae) based on plastid and nuclear sequences: proposal of the new subgenus Ecomata. Taxon 61(4): 747-763. DOI: 10.1002/tax.614004 